\title{
Kajian Orientalis Ignaz Goldziher tentang Hadis dan Sunnah
}

Cucu Setiawati

Fakultas Ushuluddin UIN Syarif Hidayatullah Jakarta

cucusetiawati715@gmail.com

\begin{abstract}
Moslem concider Hadith and Sunnah are the main sources of Islamic teachings which serve as explanations for the verses of the Qur'an. But Orientalists such as Ignaz, Goldziher has different oppinion, distinguishing between hadith and sunnah. According to him the sunnah is seen as a revision of the customs that occurred even though it did not strengthen the overall meaning. While the hadith according to him is the result of the development of Islam in the fields of religion, politics, and sociology in the period of two centuries, namely the first and second centuries. Hadith is not an Islamic document in the early days of its growth but it is the product of letter generations, after the die Prophet Muhammad SAW. In addition, the hadith is also one product generated from the effects of Islamic power that occurred at its glory.
\end{abstract}

Keywords: Hadith, Sunnah, Orientalist, Ignaz Goldziher

\begin{abstract}
Abstrak: Muslim menganggap Hadits dan Sunnah adalah sumber utama ajaran Islam yang berfungsi sebagai penjelasan untuk ayat-ayat Alquran. Tetapi orientalis seperti Ignaz Goldziher memiliki pendapat yang berbeda, membedakan antara hadits dan sunnah. Menurutnya sunnah dipandang sebagai revisi dari adat istiadat yang terjadi walaupun tidak memperkuat makna secara keseluruhan. Sedangkan hadits menurutnya merupakan hasil perkembangan Islam di bidang agama, politik, dan sosiologi dalam kurun waktu dua abad, yaitu abad pertama dan kedua. Hadis bukanlah dokumen Islam pada masa awal pertumbuhannya, tetapi merupakan produk generasi surat, setelah Nabi Muhammad SAW wafat. Selain itu, hadits juga merupakan salah satu produk yang dihasilkan dari efek kekuatan Islam yang terjadi pada kejayaannya.
\end{abstract}

Kata kunci: Hadis, Sunnah, Orientalis, Ignaz Goldziher

\section{Pendahuluan}

Salah satu kajian Islam yang penting dipelajari dan diteliti kebenarannya ada Hadis dan Sunnah. Letak pentingnya dapat dilihat bahwa Hadis merupakan sumber 
hukum kedua yang memiliki fungsi sebagai penjelas bagi ayat-ayat Alquran yang maknanya masih umum. ${ }^{1}$

Hasbī al-Șiddīqī menyebutkan bahwa ada empat fungsi utama Hadis yang berkaitan dengan Alquran di antaranya: 1) Bayān al-taqrīr memiliki fungsi untuk memberi ketetapan hukum dan menguatkan hukum dalam Alquran, 2) Bayān al-tauḍih memiliki fungsi untuk memberi penjelasan terkait maksud dari ayat Alquran, 3) Bayān al-tafṣil memiliki fungsi untuk menerangkan ayat-ayat yang sifatnya masih mujmāl dan, 4) Bayān al-bāsṭi memiliki fungsi untuk menjelaskan lebih rinci terkait keteranganketerangan dalam Alquran yang terlihat singkat. ${ }^{2}$

Secara umum, kajian Hadis menjadi pusat penelitian. Umumnya dari kalangan para ulama dan sarjana yang mengkaji dan meneliti kualitas Hadis, baik yang termuat dalam kitab Hadis maupun non Hadis, serta dari segi matan dan sanad. ${ }^{3}$

Selanjutnya, ruang lingkup kajian Hadis tidak hanya diteliti dan dipelajari oleh umat Islam saja, melainkan juga dikaji dan diteliti oleh orang-orang di luar agama Islam, bahkan orang-orang Barat sangat memiliki ketertarikan untuk ikut berpartisipasi dalam mengkaji Hadis.

Beragam sudut pandang muncul dari ulama aḥl al-Fiqh dan ulama aḥl al-Hadīis terkait defini dari Hadis dan sunnah. Selain itu, banyak dari orientalis yang melakukan interpretasi terhadap defini Hadis dan Sunnah. Hal itu semata-mata untuk memberi perbedaan antara Hadis dan Sunnah.

Pada abad pertengahan ke-19 M dalam Islam muncul pertama kali mengenai persoalan status Hadis. Dia adalah Alois Sprenger, seorang orientalis yang mulai melakukan gugatan terhadap Hadis.

Selanjutnya, dalam pengantar buku Alois Sprenger (Misionaris asal Jerman yang pernah tinggal lama di India) dijelaskan tentang riwayat hidup dan ajaran Nabi Muhammad SAW. Selain itu, ia juga memberi pernyataan bahwa Hadis adalah kumpulan dari ceri bohong yang menarik untuk dikaji.

Klaim di atas diamini oleh William Muir, dia adalah rekan satu misinya. Sebagaimana yang dikutip oleh Syamsuddin bahwasnnya Menurut William dalam

\footnotetext{
1'Abdullah Hasān al-Hadīì̄i. Ațār al-Hadīis al-Nabāwī al-Syarīf fì Ikhtilāf al-Fuqahā. Cet. 1 (Bairūt: Dār al-Quṭb al-'Ilmiyyah, 2005), 3.

${ }^{2}$ Muḥammad Hasbī al-Ṣiddīqī. Sejarah dan Pengantar Ilmu Hadis (Semarang: Pustaka Rizki Putra, 2010), 138-139.

${ }^{3}$ M. Syuhudi Ismail. Metodologi Penelitian Hadis Nabi (Jakarta: Bulan Bintang, 2007), 27.
} 
literatur Hadis, nama Nabi Muhammad SAW, sengaja dicatat untuk menutupi berbagai macam kebohongan. ${ }^{4}$

Kemudian, pada abad ke-19 M Ignaz Goldziher ${ }^{5}$, dia merupakan orientalis asal Jerman yang menulis karya mengenai Hadis dan sunnah dengan judul "Muhammedanische Studien" karya tersebut ditulis sebagai kritikan yang sangat penting mengenai Hadis. Setelah Ignaz menulis karya tersebut muncul serangan terhadap Hadis yang merupakan puncak saat itu.

Sementara itu, setelah terbitnya buku Ignaz tersebut kurang lebih enam puluh tahun. Kemudian Ignaz Goldziher dalam bukunya memberikan penjelasan mengenai perbedaan antara Hadis dan sunnah. Dan dikalangan para ulama atau sarjana muslim terjadi perbedaan mengeni pemikiran Goldziher tentang Hadis dan sunnah.

Terlepas setuju atau tidak, pandangan-pandangan Goldziher pada kenyataannya memiliki pengaruh besar terhadap sikap para tokoh yang muncul setelahnya. Kajian yang serius tentang sejarah tulis-menulis dan relevansinya dengan periwayatan Hadis, sebagaimana yang dilakukan oleh Syiekh Rāsyid Riḍā ${ }^{6}$ dan Gregor Schoeler. ${ }^{7}$ Oleh karena itu, makalah ini mencoba mendiskusikan Bagaimana Kajian Hadis dan Sunnah dalam panfangan orientalis Ignaz Goldziher?.

Informasi seputar Hadis dan sunnah didiskusikan melalui sumber utama karya Ignaz Goldziher yaitu Muhammadanische Studien, sebuah karya dari Ignaz Goldziher yang berisi kajian kritis paling fundamental tentang Hadis yang diterjemahkan ke dalam bahasa Inggris oleh S.M. Stern dan Barber yang diberi judul "Muslim Studies". Jiilid pertama diterbitkan oleh George Allen \& Unwin Ltd pada tahun 1967, sementara jilid kedua diterbitkan pada tahun 1971 oleh penerbit yang sama. Edisi Inggris jilid pertama terdiri dari 254 halaman, sementara jiilid kedua terdiri dari 378 halaman.

\footnotetext{
${ }^{4}$ Syamsuddin Arif, Orientalis dan Diabolisme Pemikiran (Jakarta: Gema Insani, 2008), 28.

${ }^{5}$ Alam Khan, "Distortion of Facts and History in 'Muslim Studies' by Ignaz Goldziher Chapter II As A Model”, Asian Journal of Social Sciences \& Humanities 5, (2016), 110.

${ }^{6}$ Diskusi hangat, khususnya di Mesir tentang Hadis-Hadis yang membolehkan dan melarang penggunaan tulisan untuk mencatat Hadis Nabi, di antaranya yang disampaikan oleh Rāsyid Riḍā, bisa dilihat dalam tulisan G.H.A. Juynboll, The Authenticity of the Muslim Literature: Discussions in Modern Egypt (Leiden: Brill, 1969).

${ }^{7}$ Gregor Schoeler, The Oral and the Written in Early Islam, terj. Owe Vagelpohl (London: Routledge, 2006).
} 
Sebelumnya pembahasan makalah ini diawali dengan biografi Ignaz Goldziher, karya-karya Ignaz Goldziher, pemikiran Ignaz Goldziher tetang Hadis dan sunnah, kritik sarjana barat dan muslim mengenai Ignaz Goldziher, dan kesimpulan.

\section{Biografi Ignaz Goldziher}

Orientalis Barat ini bernama Ignaz Goldziher. Ia lahir tanggal 22 Juni 1850 di kota Székesfehérvar, Hongaria. Keluarganya adalah keturunan Yahudi yang terpandang dan memiliki pengaruh yang cukup besar di masyarakat saat itu. Goldziher sudah mampu membaca teks Bible dalam bahasa Ibrani sejak usia 5 tahun. Selanjutnya pada usia delapan tahun, dia mampu membaca kitab Talmud. Dan pada usia dua belas tahun, dia mempublikasikan karya yang pertama tentang asal-usul dan klasifikasi doa-doa ibrani. ${ }^{8}$

Goldziher mulai menempuh Pendidikan sejak usia 15 tahun di Universitas Budapest, Hungaria. Pemikiran Goldziher dipengaruhi oleh pemikiran dosennya yang bernama Aminus Vambery (1832-1913). Dosen Goldziher tersebut adalah dosen yang ahli tentang Turki dan seorang pengembara. Kehidupan intelektual Goldziher banyak diwarnai oleh Aminus Vambery. Setelah menyelesaikan pendidikannya di Budapest, Goldziher memiliki keilmuan intelektual yang sangat bermutu. ${ }^{9}$

Saat berusia 16 tahun, Goldziher berhasil mempelajari tentang manuskripmanuskrip Arab di Leiden dan Wiena. Selain itu, Goldziher terpilih menjadi salah satu dari anggota pertukaran pelajar. Pada saat itu, Goldziher melaksanakan perjalanan dan ekspedisi di kawasan Timur Tengah, kemudia menetap di Kairo. Selama di Kairo, Goldziher sempat bertukar kajian di Universitas al-Azhar. ${ }^{10}$

Pada tahun 1873-1874, Goldziher berkunjung ke beberapa negara Muslim. Hal itu dilakukan Goldziher untuk bisa bertemu dan berinteraksi dengan beberapa para ulama. Dia mengunjungi Syiria dan Mesir untuk bisa mendapatkan ilmu pengetahuan terkait Islam. $^{11}$

Kemudian di Mesir Goldziher dikenalkan oleh Dor Bey (Edouard Dor), seorang pejabat Inspektur Jendral Madrasah pada masa khodive Ismail di Mesir. Melalui Dor

${ }^{8}$ Ignaz Goldziher, Pengantar Teologi dan Hukum Islam, terj. Hesri Setiawan (Jakarta: INIS. 1991), 3.

${ }^{9}$ A. Muin, Orientalisme dan Studi tentang Islam (Jakarta: Bulan Bintang, 1978), 46.

${ }^{10}$ Mohammad Anwar Syarifuddin, Kajian Orientalis terhadap Alquran dan Hadis (Ciputat: Sekata Cendikia, 2015), 65.

${ }^{11}$ Mohammad Anwar Syarifuddin, Kajian Orientalis terhadap Alquran dan Hadis, 66. 
Bey diperkenalkan Goldziher kepada Riyad Pasha, Menteri Pendidikan Mesir. Ketika itu Goldziher memperkenalkan dirinya sebagai Ignaz al-Maghyar (Ignaz dari Hungaria) dan mengaku dirinya sebagai "Muslim". Goldziher melakukan usaha tersebut dengan maksud dan tujuan agar bisa belajar di Universitas al-Azhar. ${ }^{12}$

Ketekunan dan keteguhan Goldziher belajar di Universitas al-Azhar membuahkan hasil. Akhirnya Goldziher menjadi murid beberapa masyāyikh al-Azhar, seperti Syaikh al-Asmāwī, Syaikh Mạ̣fūz al-Maghrībī, Syaikh Sakkā’ dan beberapa Syaikh al-Azhar lainnya. $^{13}$

Goldziher melanjutkan pendidikannya ke Universitas Leipzig pada tahun 1874 dalam usia 19 tahun. Pendidikannya di Leipzing tersebut, ditempuhnya dengan mendapatkan beasiswa dikarenakan ia mempunyai keilmuan yang sangat luar biasa. Sampai pada akhirnya, Goldziher pun mendapatkan gelar Doktor di Universitas tersebut. Setelah itu, Goldziher melanjutkan penelitiannya di Leiden, Belanda saat ia berusia 20 tahun. $^{14}$

Selanjutnya, pada usia 21 tahun Goldziher pulang ke kampung halamannya dan menjadi dosen privat di Universitas Budapest, Hungaria. Goldziher juga dipilih sebagai anggota "Akademi Sains Hungaria", sebuah penghargaan yang diberikan kepada dirinya. $^{15}$

Selanjutnya, Goldziher mulai menjadi dosen pada tahun 1904. Adapun mata kuliah yang diajarkannya adalah bahasa Hebrew dan Ibrani. Di samping itu, pemerintah Hungaria pernah memberikan beasiswa kepada Ignaz Goldziher untuk mempelajari keilmuan di Universitas al-Azhar. Hal itu dijadikan sebagai pengalaman yang paling berharga. ${ }^{16}$ Setelah itu, Goldziher melanjutkan karirnya untuk mengajarkan bahasa semit di Universitas Budapes sampai akhir hidupnya. Goldziher meninggal dunia tanggal 13 November 1921, diusia 71 tahun. $^{17}$

\footnotetext{
${ }^{12}$ A. Muin. Orientalisme dan Studi tentang Islam, 47.

${ }^{13}$ Ignaz Goldziher, Pengantar Teologi dan Hukum Islam, ix.

${ }^{14}$ Ignaz Goldziher, Pengantar Teologi dan Hukum Islam, xiii.

${ }^{15}$ Ignaz Goldziher, Pengantar Teologi dan Hukum Islam, ix.

${ }^{16}$ Ignaz Goldziher, Pengantar Teologi dan Hukum Islam, xiii.

${ }^{17}$ A. Muin. Orientalisme dan Studi tentang Islam. (Jakarta: Bulan Bintang. 1978). h. 49.
} 


\section{Pengertian dan Asal Usul Hadis dan Perkembannya}

Menurut Goldziher, makna Hadis secara terminologi ialah suatu komunikasi dan kisah dan sejarah, baik yang bersifat sekular maupun keagamaan, pada masa lampau ataupun masa yang akan datang. Kemudian dalam konteks sebuah legenda atau dongeng, Hadis juga dipraktikkan untuk subjek sebuah cerita tertentu. Sehingga ada pernyataan "Menjadi suatu Hadis". Pernyataan tersebut merupakan contoh yang akan selalu diceritakan oleh generasi mendatang. ${ }^{18}$

Goldziher mengatakan bahwa yang dimaksud dengan Hadis adalah tutur atau pengkabaran yang berlaku dikalangan para penganut kehidupan kerohanian. Di samping itu Hadis juga merupakan data sejarah yang bersifat duniawi maupun keagamaan baik yang berasal dari zaman yang silam maupun tentang peristiwaperistiwa dari zaman yang paling akhir. Dalam pemakaian linguistik, perkataan Hadis sudah sejak zaman dahulu dikhususkan dalam dunia keagamaan, yaitu untuk suatu jenis tutur atau perkabaran tertentu tanpa melepaskan dari konteksnya yang umum. ${ }^{19}$

Dalam konteks di atas Goldziher mengemukakan sebuah ilustrasi mengenai perjalanan ucapan-ucapan Nabi sejak diucapkannya hingga menjadi bahan-bahan dasar Hadis, yaitu sebagai berikut:

"Para pengikut nabi yang salih dengan takzimnya mengulang ucapanucapan panutan mereka yang memberikan penerangan itu, dan berusaha menyimpannya sebagai pembangun keimanan dan petunjuk bagi umat terhadap segala hal-ihwal yang telah diucapkannya baik dimuka umum maupun yang bersifat pribadi, mengenai pengamalan-pengamalan kewajiban agama seperti yang telah dia contohkan. Perilaku dalam kehidupan pada umumnya dan tata krama kemasyarakatan, baik yang berhubungan dahulu maupun yang akan datang. Ketika perang penaklukan yang terjadi berturut-turut dengan cepat membawa mereka ke negeri-negeri jauh, Hadis-Hadis nabi disampaikannya kepada orang-orang yang belum pernah mendengarnya secara langsung. Dan sesudah ia meninggal, merekapun banyak menambahkan ucapan-ucapan bermanfaat yang dipandang sejalan dengan jalan pemikirannya. Hadis-Hadis ini berkenaan dengan praktik-praktik keagamaan dan hukum yang telah terbentuk selama masa Nabi dan dipandang sebagai perangkat kaidah bagi seluruh dunia Islam". ${ }^{20}$

\footnotetext{
${ }^{18}$ Ignaz Goldziher, Muslim Studies, terj. S.M. Stern \& C.R. Barber, jidil 2 (London: George Allen \& Unwin, 1971), 18.

${ }^{19}$ Ignaz Goldziher, Muslim Studies, jilid 2, 17.

${ }^{20}$ Ignaz Goldziher, Muslim Studies, 18.
} 
Berdasarkan pernyataan di atas, Goldziher menyimpulkan bahwa sebagian besar Hadis merupakan hasil kelanjutan dari agama, sejarah dan masyarakat Islam selama dua abad pertama hijriyah dan Hadis tidaklah berfungsi sebagai dokumen sejarah Islam masa awal perkembangannya saja, akan tetapi lebih banyak sebagai gambaran kecenderungan- kecenderungan yang muncul di tengah-tengah umat Islam selama masa-masa perkembangannya yang telah lebih dewasa. ${ }^{21}$

Goldziher juga mengilustrasikan proses perkembangan pengertian Hadis dikalangan umat Islam dari maknanya yang umum menjadi khusus, sebagai suatu berita, catatan atau laporan yang berasal dari Nabi Muhammad sebagai sumber tunggal. Akan tetapi, Goldziher menyangsikan keberadaan Hadis dengan pengertian khusus seperti itu. Ia tidak mempercayai Hadis sebagai sesuatu yang seluruhnya bersumber dari Nabi Muhammad SAW, Goldziher mengatakan:

\begin{abstract}
"Hadis tidak hanya berfungsi sebagai catatan masa awal sejarah Islam pertumbuhan saja, melainkan lebih banyak sebagai kecenderungankecenderungan yang muncul di tengah-tengah umat selama masa-masa perkembangannya yang telah lebih dewasa. Di dalamnya terkandung bukti yang tidak ternilai mengenai evolusi Islam, selama tahun-tahun pembentukan dirinya menjadi suatu keutuhan yang terorganisasi dari kekuatan-kekuatan yang kokoh dan saling bertentangan itu. Ini berarti tanggapan yang setepatnya serta studi terhadap Hadis menajadi sangat penting guna pemahaman terhadap Islam, mengingat tahap-tahap penting dalam evolusinya selalu diiringi oleh tingkat-tingkat penciptaan Hadis secara berturut-turut". ${ }^{22}$
\end{abstract}

Seiring perkembangannya Goldziher berpendapat bahwa Hadis mempunyai kesamaan dengan bid'ah, karena Hadis adalah muhdās yang memiliki makna sesuatu yang baru. Sementara itu, Muḥammad Ajaj al-Khāṭib menyebutkan bahwa Hadis secara etimologi al-Jadīd yang berarti perkara-perkara baru yang bermakna berita, baik sedikit ataupun banyak.

Dengan demikian, para muhaddisīn berpendapat bahwa secara terminologi arti Hadis dan maknanya sama dengan sunnah yaitu Semua hal yang berasal dari Nabi Muhammad SAW. Namun jika lafā̇ Hadis dimaknai secara umum, maka bermakna

\footnotetext{
${ }^{21}$ Ignaz Goldziher, Muslim Studies, 19.

${ }^{22}$ Ignaz Goldziher, Muslim Studies, 38.
} 
segala sesuatu yang diriwayatkan dari Nabi Muhammad SAW, setelah kenabian, baik perkataan, perbuatan, maupun taqrīr (ketetapan). ${ }^{23}$

Pendapat tersebut berbeda dengan pendapat Ignaz Goldziher. Hal itu dikarenakan, kata Hadis yang diambil olehnya bukanlah berasal dari kata hadasiana, melainkan menggunakan kata aḥdasa, kemuidan kata tersebut dimaknai dengan sesuatu yang baru. ${ }^{24}$ Dengan begitu, jelas akan tertolak bagi siapa pun yang melakukan suatu hal baru. Sebab hal itu mengindikasikan bahwa Hadis adalah hal baru yang dibuat oleh Nabi Muhammad. Dengan demikian, tidak bisa dipakai untuk menjadi sumber hukum Islam.

\section{Hadis Terdiri dari Unsur Sanad dan Matan}

Disini Goldziher lebih menekankan pembahasan tentang pengertian kata matan yang menurut Goldziher berasal dari masa pra Islam yang semula tidak mengandung pengertian "bunyi Hadis", tetapi berarti "naskah tertulis".

Dengan demikian, dia menyanggah asumsi yang mengatakan, bahwa Hadis dalam bentuk aslinya tidak tertulis tetapi hanya terbatas pada tutur-tutur secara lisan saja. $^{25}$

\section{Perbedaan Hadis dengan Sunnah}

Goldziher membedakan Hadis dengan Sunnah. Sunnah merupakan praktik yang telah menjadi kebiasaan, tata cara mengenai adab atau norma yang telah disetujui oleh tradisi.

Menurut Goldziher, konsep Sunnah seperti ini sejak awal sudah ada. Kekuatan sunnah sebagai asas normatif bagi kehidupan orang Islam sudah terbentuk sejak akhir abad pertama hijriyah. Kekuatan ini terus menerus bertambah bersamaan dengan babak-babak sejarah. Usaha untuk mengangkat sunnah pada kedudukan yang setara dengan kitab suci guna pembentukan hukum semakin lama semakin nyata.

Dengan perkembangan teologi Hadis, sunnah dan Alquran dipandang mempunyai kedudukan yang sama-sama penting antara abad ke-2 dan ke-3 hijriyah.

\footnotetext{
${ }^{23}$ Muḥammad Ajaj al-Khāthib, Ușūl al-Hadis: 'Ulūmuhu wa Muștalāḥuhu (Bairūt: Dār al-Fikr, 2008), 19.

${ }^{24}$ Ayub, "Matn Criticism And Its Role In The Evaluation Of Hadith Authenticity", IJISH: International Journal of Islamic Studies and Humanities, (2018), 70.

${ }^{25}$ Ignaz Goldziher, Muslim Studies, 38.
} 
Mengikuti kaum salaf, yaitu nenek moyang orang-orang Mukmin yang membentuk kebiasaan hidupnya di bawah pengawasan dan dengan teladan Nabi, menjadi semakin diidam-idamkan oleh orang-orang Islam yang salih. Pandangan hidup ini benar-benar mengembangkan orang-orang yang begitu fanatik terhadap sunnah, di mana-mana mereka mencari data tentang kebiasaan-kebiasaan Nabi dan berusaha untuk mempraktikkannya. ${ }^{26}$

\section{Kritik Sarjana Barat dan Muslim Terhadap Kajian Hadis Ignaz Goldziher}

Buku Muhammadanische Studien karya Ignaz Goldziher merupakan karya monumental dan telah menjadi inspirator dan bahkan karya ini dipandang sebagai "kitab suci" oleh para orientalis dalam studi Hadis. Juynboll dalam bagian pendahuluan bukunya yang berjudul Muslim Tradition mengatakan, bahwa karya Ignaz Goldziher merupakan karya ternama setidaknya di dunia Barat, sebagai fondasi awal dari usaha-usaha ilmuwan Barat untuk melukiskan sejarah Hadis yang paling awal. $^{27}$

Joseph Somogy mengatakan bahwa karya yang dihasilkan Goldziher telah banyak memberikan penghargaan kepada dunia Islam, sehingga merupakan kontribusi dalam memantapkan keharmonisan antara Timur dan Barat. ${ }^{28}$

Menurut Charles J. Adam, sebagai karya ilmiah yang muncul pada saat itu (tahun 1889 M) buku Muhammedanische Studies sedemikian solid dan sudah tertanam di lapangan ilmu pengetahuan dengan argumen-argumen yang meyakinkan dan selama tenggang waktu 70 tahun tidak ada karya lain yang menandinginya. ${ }^{21}$ Oleh karena itu, tidak mengherankan bila karya Ignaz Goldziher ini mempunyai pengaruh sedemikian besar terhadap orientalis sesudanya, terutama dalam studi Hadis.

Joseph Schacht, adalah seorang orientalis yang termasuk dalam kelompok ini. Dalam bukunya The Origin of Muhammad Jurisprudence, yang kemudian diulanginya kembali dalam karyanya yang lain an Introduction to Islamic Law, sarjana kelahiran Ratibor, Jerman, ini mengatakan bahwa Hadis sebagaimana yang kita ketahui sekarang tidak ada di masa Nabi Muhammad atau sebagian besar dari

\footnotetext{
${ }^{26}$ Ignaz Goldziher, Muslim Studies, 31-32.

${ }^{27}$ Ignaz Goldziher, Muslim Studies, 126-144.

${ }^{28}$ Ignaz Goldziher, Muslim Studies, 181-188.
} 
abad pertama Islam. Hadis sebagai sesuatu perkataan dan perbuatan Nabi yang kita kenal sekarang lahir baru di akhir abad pertama hijrah. ${ }^{29}$

Untuk membuktikan pendapatnya di atas, sarjana yang ketika itu masih berumur 21 tahun sudah meraih gelar doktor ini mengemukakan sebuah teori yang dia sebut "Projecting Back" (Proyeksi ke Belakang), yaitu menisbatkan pendapat para ahli fiqh abad ke-2 dan ke-3 hijriyah kepada para tokoh sebelumnya sampai kepada nabi, sehingga membentuk sanad Hadis. Hal ini mereka lakukan dengan tujuan pendapat tersebut memiliki legalitas dari orang-orang yang mempunyai pengaruh lebih tinggi. Oleh karena itu, menurut Schacht, Hadis-Hadis itu tidak orisinil berasal dari nabi, melainkan rekayasa ulama abad kedua dan ketiga hijriyah. ${ }^{30}$

Selain Schacht, masih banyak lagi tokoh-tokoh orientalis lain yang terpengaruh oleh karya Ignaz Goldziher ini, misalnya Theodor Noldeke, C.H. Becker, A. Guillaume, Robson, dan sebagainya.

M.M. Azami mengatakan, bahwa karya Guillaume yang berjudul "The Traditions of Islam", sama sekali tidak menyuguhkan sesuatu yang baru dalam penelitian Hadis melainkan hanya mengandalkan buku Muhammadanische Studien karya Ignaz Goldziher.

Demikian halnya dengan kitab "Misykāh al-Mașābiḥ" dan "al-Madkhāl” karya al-Ḥākim yang diterjemahkan oleh Robson banyak terkecoh oleh teori-teori Schacht yang tidak lain dari pengikut setia Ignaz Goldziher. ${ }^{31}$

Tidak hanya di Barat, pemikiran Ignaz Goldziher juga telah mempengaruhi sebagian cendikiawan muslim yang belajar di universitas-universitas Barat. Sebut saja, misalnya Aḥmad Amān dalam bukunya Fajr al-Islām dan Mạ̣mūd Abū Rayyā' dalam A Sunnah al-Nabawiyyah Bain Ahl al-Fiqh wa Ahl al-Hadìs, dan dalam kajian-kajian yang lain banyak melakukan kritik Hadis dengan prinsip-prinsip seperti yang dianut Goldziher.

Cendikiawan muslim lainnya yang terpengaruh oleh pemikiran Ignaz Goldziher adalah Āli Ḥasān 'Abd al-Qadīr. Hal ini terlihat dalam pidatonya ketika menyampaikan kuliah perdana di Universitas Al-Azhar dia mengatakan, bahwa "saya

\footnotetext{
${ }^{29}$ Ignaz Goldziher, Muslim Studies, 189-251.

${ }^{30}$ Joseph Somogy, "Ignaz Goldziher", Moslem World 41, 1 (1951), 201.

${ }^{31}$ Ali Mustafa Yaqub, Kritik Hadis (Jakarta: Pustaka Firdaus, 1996), 27-28.
} 
hendak memberikan kuliah kepada saudara-saudara tentang Tarikh Hadis Nabi dengan menggunakan cara-cara ilmiah yang belum pernah saya temukan sebelumnya, termasuk selama saya kuliah di Al-Azhar selama 14 tahun."

Setelah pidato tersebut selesai, ternyata bahan pidato tersebut hanyalah terjemahan harfiah dari buku "Muhammadanische Studiien” karya Ignaz Goldziher. Buku inilah yang disebutnya sebagai buku ilmiah. ${ }^{32}$

Karya Ignaz Goldziher juga telah mengilhami banyak universitas terkemuka di Eropa dan Amerika untuk membuka jurusan Islamic Studies (Arabic Studies).

Di antara universitas-universitas dimaksud adalah Universitas London, Oxford, Cambridge, Edienburgh, Leiden, Glasgow, Mac Gill, Colombia, Harvard, dan lain sebagainya.

Dalam proses belajar-mengajar, mereka berusaha keras agar karya-karya Goldziher, Margoliouth, dan Joseph Schacht tetap menjadi referensi orisinal untuk mahasiswa-mahasiswanya. Bagi mahasiswa-mahasiswa muslim yang akan menempuh Ph.D tidak pernah akan disetujui disertasinya apabila tema yang diajukan berkenaan dengan keadilan Islam dan membongkar tipu daya orientalis. ${ }^{33}$

Hal ini, misalnya dialami oleh Amir Mishri, alumnus Fakultas Ushuluddin Universitas Al-Azhar Cairo. Ia menceritakan pengalamannya dalam mengajukan topik disertasinya dalam mencapai doktor dalam ilmu filsafat di UniversitasUniversitas Inggris. Judul disertasi yang ia ajukan adalah "Kritik Terhadap Buku Schacht tentang Sejarah Fikhi Islam”. Akan tetapi judul yang ia ajukan tersebut ditolak Prof. Anderson, yang bertindak sebagai promotor. Alasannya adalah karena judul disertasi tersebut mengkritik Schacht. Setelah putus asa di Universitas London, Amir Mishri lalu pergi ke Universitas Cambridge sebagai “affiliation student" dan kembali mengajulan judul yang sama kepada para pembimbing dengan harapan dapat diterima sebagai judul disertasi. Tapi persetujuan itu tidak kunjung datang. Akhirnya, dengan terus terang mereka mengatakan bahwa jika anda ingin menyelesaikan dan meraih gelar doktor, janganlah sekali-kali mengeritik Schacht karena pihak universitas tidak memperbolehkan hal demikian terjadi. ${ }^{34}$

\footnotetext{
${ }^{32}$ Joseph Schacht, An Introducton toIslamic Law (Oxford: Clarendom Press, 1964), 17.

${ }^{33}$ Joseph Schacht, An Introducton toIslamic Law (Oxford: Clarendom Press, 1964), 164.

${ }^{34}$ M.M. Azami, Dirāsat fī al-Hadis al-Nabāwī wa Tarīkh Taḍ̂̄nihi, Jilid 3 (Bairūt: al-Makatab alIslāmī, 1980), 398.
} 


\section{Kesimpulan}

Dari pembahasan makalah di atas, penulis menyimpulkan bahwa Hadis dan sunnah menurut Goldziher sebagai berikut.

Hadis merupakan berita lisan yang bersumber dari nabi, yang ditekankan di sini adalah keberadaan Hadis sebagai berita lisan, bukan keberadaan Nabi sebagai sumbernya. Sedangkan sunnah, sebagaimana lazimnya dalam pandangan umat Islam terdahulu merujuk kepada berita lisan, baik ada ataupun tidak ada mengenai permasalahan hukum atau keagamaan tersebut. Pada umumnya Hadis dipandang sebagai sunnah, akan tetapi setiap sunnah tidak mesti mempunyai Hadis yang bersesuaian dan mengukuhkannya. Bahkan mungkin sekali terjadi pertentangan antara Hadis dan sunnah atau katakanlah hukum adat yang berlaku.

Di dalam literatur bidang studi, Hadis merupakan suatu disiplin teoritis sementara sunnah merupakan suatu karangan ilmiah yang berisi aturan-aturan praktis. Persamaan sifat di antara Hadis dan sunnah ialah produk perkembangan aspek keagamaan, sejarah, dan sosial dalam Islam yang baru muncul sejak abad ke-2 $\mathrm{H}$, dimana pengetahuan mengenai keduanya berakar pada tutur atau berita lisan secara turun-temurun.

Selanjutnya, Dalam mengkritik Ignaz goldziher, lihatlah Ignaz sebagai ilmuwan yang terikat oleh prinsip-prinsip ilmiah yang harus objektif dan tidak berperasaan. Jadi pikiran yang dituangkan Ignaz adalah sesuatu yang dapat dipertanggung jawabkan. Itu adalah ideal formatifnya dari pemikiran Ignaz Goldziher mengenai Hadis dan sunnah. Dari kajian Ignaz Goldziher mengenai Hadis dan sunnah, penulis setuju mengenai Ignaz Goldziher yang menjaga prinsipnya dengan sangat baik, akan tetapi tetap saja, tidak ada individu yang sempurna selalu ada celah untuk mengkritik. Bagaimanapun Ignaz dibesarkan dalam tradisi non Islam yaitu tradisi Yahudi dan Nasrani. Karena itu mungkin ada baiknya kita melihat Ignaz sebagai ilmuwan.

Oleh karena itu, sangat besar pengaruh Ignaz goldziher bagi para sejarawan. Ignaz mengawalinya dengan excellent (keunggulan), maka tidak mudah bagi sejarawan lainnya untuk tidak mengapresiasi kontribusi Ignaz goldziher, jadi Ignaz disebut sebagai bapak kajian islamic studies dikalangan orientalis dan itu hebat sekali. 


\section{Daftar Pustaka}

Arif, Syamsuddin. Orientalis dan Diabolisme Pemikiran. Jakarta: Gema Insani, 2008. Ayub. "Matn Criticism And Its Role In The Evaluation Of Hadith Authenticity". IJISH (International Journal of Islamic Studies and Humanities), 2018.

Azami, M. M. Dirāsat fì al-Hadīs al-Nabāwì wa Tarīkh Taụwīnihi. Bairūt: al-Makatab al-Islami, 1980.

Badawi, Abdurrahman. Ensiklopedia Tokoh Orietalis; Irwan Masduqi. "Ignaz Goldziher" diakses pada 10 November 2018 dari http://irwanmasqudi83.blogspot.com/Ignaz-Goldziher-oleh-irwan-masqudidi.html.

Goldziher, Ignaz. Muslim Studies. Terj. S.M. Stern \& C.R. Barber. London: George Allen \& Unwin, 1971.

Goldziher, Ignaz. Pengantar Teologi dan Hukum Islam. Terj. Hesri Setiawan. Jakarta: INIS, 1991.

Al-Hadīìī, 'Abdullah Ḥasān. Ațhar al-Hadịs al-Nabāwī al-Syarīf fì Ikhtilāf al-Fuqahā. Bairūt: Dār al-Quṭb al-'Ilmiyyah, 2005.

Ismail, M. Syuhudi. Metodologi Penelitian Hadis Nabi. Jakarta: Bulan Bintang, 2007.

Juynbol, G.H.A. The Authenticity of the Muslim Literature: Discussions in Modern Egypt. Leiden: Brill, 1969.

Al-Khāṭib, Muḥammad Ajaj. Ușūl al-Hadīs: 'Ulūmuhu wa Muștalāḥhu. Bairūt: Dār al Fikr, 2008.

Muin, A. Orientalisme dan Studi tentang Islam. Jakarta: Bulan Bintang, 1978.

Mutmainah. "Hadis dalam Perspektif Goldziher". (Skripsi Institut Ilmu Alquran Jakarta), 2008.

Schacht, Joseph. An Introducton toIslamic Law. Oxford: Clarendom Press, 1964.

Schoeler, Gregor. The Oral and the Written in Early Islam. Terj. Owe Vagelpohl. London: Routledge, 2006.

Al-Ṣiddīqī, Muhammad Ḥasbī. Sejarah dan Pengantar Ilmu Hadits. Semarang: Pustaka Rizki Putra, 2010.

Syarifuddin, Mohammad Anwar. Kajian Orientalis terhadap Alquran dan Hadis. Ciputat: Sekata Cendikia, 2015.

Yaqub, Ali Mustafa. Kritik Hadis. Jakarta: Pustaka Firdaus, 1996. 